\title{
The Management of Foreign Body Displacement into the Maxillary Sinus as a Complication of Maxillofacial Interventions: Systematic Review
}

\author{
Bartosz Wojtera $^{1} \cdot$ Angelika Woźna $^{1} \cdot$ Oskar Komisarek $^{2}$ (B)
}

Received: 15 July 2020/Accepted: 14 September 2020/Published online: 18 September 2020

(C) The Author(s) 2020

\begin{abstract}
Displacement of foreign bodies into the maxillary sinus shows an increasing tendency, especially in regard to raising amount of dental implant installation procedures. The purpose of our study was to compare the efficiency and the rate of late complications among the methods of removal of foreign bodies from maxillary sinus. We performed a systematic review following PRISMA Checklist, searching Pubmed and Google Scholar databases for studies investigating the methods of removal of foreign bodies from maxillary sinus. The inclusion criteria embraced the examined group of at least 10 cases and the follow up period of minimum 3 months. We qualified 7 papers from 531 identified in primary search. Among qualified studies functional endoscopic sinus surgery used in order to remove foreign body from maxillary sinus had no late complications, whereas they occurred in $0-5 \%$ cases of using replaceable or pedicled bone approaches and in $15-18 \%$ cases of Caldwell-Luc approach. FESS probably should become a gold standard in retrieving foreign bodies from maxillary sinus, however poor evidence requires further investigation, especially in prospective, randomized trials.
\end{abstract}

Keywords Foreign body · Maxillary sinus ·

Complications $\cdot$ Implants

Oskar Komisarek

oskarkomisarek@gmail.com

1 Students Research Group of Maxillofacial Orthopaedics and Orthodontics, Poznan University of Medical Sciences, ul. Bukowska 70, 60-812 Poznan, Poland

2 Department of Maxillofacial Orthopaedics and Orthodontics, Poznan University of Medical Sciences, ul. Bukowska 70, 60-812 Poznan, Poland

\section{Introduction}

The anatomic conditions of maxillary sinus carry the risk of complications, when medical procedures are performed in this region. Iatrogenic displacement of foreign body into the maxillary sinus shows increasing tendency, especially in regard to raising amount of dental implant installation procedures and their further accidental migration [1]. Other types of objects dislocated into the sinus during medical procedures include fractured teeth roots [2], whole teeth [3], endodontic materials and tools [4, 5], dental filling materials [6,7], dental burs [8], or dental impression materials [9]. Not only dental procedures might induce a foreign body into the sinus-the complication can be caused by otorhinolaryngologists by accidental leaving of gauzes used to nasal or sinus packing [5], or other materials [10].

Removal of the displaced foreign body might cause major difficulties regarding a method of management and ability to perform certain procedures. There is a deficiency of reliable guidelines how to treat the displaced object [11].

The aim of the study was to compare efficiency and late complications related to foreign body removal procedures reported in literature.

\section{Methods}

The systematic review was performed following the PRISMA checklist-Preferred Reporting Items for Systematic Reviews and Meta-Analyses [12]. There is no existing study protocol indicating the justification, hypothesis nor specific methods. The review is not registered in the Prospective International Register of 
Systematic Reviews (PROSPERO), due to not meeting registration criteria.

The systematic review followed PICO Framework: P (population) refers to patients with foreign body displaced into the maxillary sinus, as the complication of interventions in the maxillofacial region; I (intervention) and $\mathrm{C}$ (comparison) referring to the certain methods of removal of foreign body; and $\mathrm{O}$ (outcome) refers to the possible late complications in the certain methods of removal follow-up.

The inclusion criteria concerned original studies referred to removal of maxillary sinus displaced foreign bodies with at least 10 cases described in the article and the minimum follow-up period of 3 months.

All studies, which had not met the inclusion criteria were rejected, as well as reviews, single case reports, letters to the editors and chapters of books. We omitted all non-English language articles.

We performed a research on PubMed and Google Scholar databases in using following keywords: foreign body, root, tooth, implant, endodontic material, retrieval, removal, displacement, maxillary sinus, paranasal sinus, antrum and their plural forms in titles and abstracts.

Table 1 Qualified studies detailed characteristics

\begin{tabular}{|c|c|c|c|c|c|c|c|c|}
\hline Title & $\begin{array}{l}\text { Author, } \\
\text { country }\end{array}$ & Year & $\begin{array}{l}\text { Type of Foreign Body } \\
\text { (FB) }\end{array}$ & Method of removal & $\begin{array}{l}\text { No. } \\
\text { of } \\
\text { FB }\end{array}$ & $\begin{array}{l}\text { Late } \\
\text { complications }\end{array}$ & $\begin{array}{l}\text { Type of } \\
\text { complications }\end{array}$ & $\begin{array}{l}\text { Follow } \\
\text { up } \\
\text { (months) }\end{array}$ \\
\hline $\begin{array}{l}\text { Retrieval of Root } \\
\text { Fragment in } \\
\text { (...) [2] }\end{array}$ & $\begin{array}{l}\text { Hu et al. } \\
\text { Egypt, } \\
\text { China }\end{array}$ & 2015 & Fractured Roots & Replaceable bone lid & 21 & $5 \%(\mathrm{n}=1)$ & $\begin{array}{l}\text { Nasal } \\
\text { discharge } \\
\text { and feeling } \\
\text { of fullness }\end{array}$ & $3-36$ \\
\hline \multirow[t]{2}{*}{$\begin{array}{l}\text { The management } \\
\text { of } \\
\text { complications } \\
\text { of following } \\
\text { displacement } \\
\text { (...) [15] }\end{array}$} & \multirow[t]{2}{*}{$\begin{array}{l}\text { Chiapasco } \\
\text { et al. } \\
\text { Italy }\end{array}$} & \multirow[t]{2}{*}{2009} & \multirow[t]{2}{*}{ Dental implants } & $\begin{array}{l}\text { Nasal endoscopy } \\
\text { Replaceable bone lidor pedicled } \\
\text { bone lid }\end{array}$ & $\begin{array}{l}6 \\
17\end{array}$ & $\begin{array}{l}- \\
6 \%(\mathrm{n}=1)\end{array}$ & $\begin{array}{l}- \\
\text { Maxillary } \\
\text { sinusitis } \\
2 \text { years } \\
\text { after } \\
\text { procedure }\end{array}$ & \multirow[t]{2}{*}{24} \\
\hline & & & & $\begin{array}{l}\text { Nasal } \\
\text { Endoscopy }+ \text { communication } \\
\text { closure }\end{array}$ & 4 & - & - & \\
\hline \multirow{3}{*}{$\begin{array}{l}\text { Complications } \\
\text { and } \\
\text { management } \\
\text { of implant } \\
\text { migrated }(\ldots) \\
{[16]}\end{array}$} & \multirow{3}{*}{$\begin{array}{l}\text { Manor et al. } \\
\text { Israel }\end{array}$} & \multirow{3}{*}{2018} & \multirow[t]{3}{*}{ Dental implants } & Caldwell-Luc & 52 & $15 \%(\mathrm{n}=8)$ & \multirow[b]{2}{*}{$\begin{array}{l}\text { Maxillary } \\
\quad \text { sinusitis } \\
\text { and/or } \\
\text { oroantral } \\
\text { fistula } \\
- \\
-\end{array}$} & \multirow[t]{3}{*}{$>12$} \\
\hline & & & & $\begin{array}{l}\text { Nasal endoscopy } \\
\text { Nasal endoscopy }+ \text { Caldwell } \\
\text { Luc }\end{array}$ & $\begin{array}{l}1 \\
1\end{array}$ & $\begin{array}{l}- \\
- \\
-\end{array}$ & & \\
\hline & & & & Spontaneous & 1 & - & - & \\
\hline $\begin{array}{l}\text { Displacement of } \\
\text { dental } \\
\text { implants into } \\
\text { (...) }[1]\end{array}$ & $\begin{array}{l}\text { Sgaramella } \\
\text { et al. } \\
\text { Italy }\end{array}$ & 2016 & Dental implants & $\begin{array}{l}\text { Replaceable bone lid or Calwell- } \\
\text { Luc }\end{array}$ & 21 & - & - & 12 \\
\hline $\begin{array}{l}\text { Transnasal } \\
\text { endoscopic } \\
\text { removal of } \\
\text { (...) }[14]\end{array}$ & $\begin{array}{l}\text { Matti et al. } \\
\text { Italy }\end{array}$ & 2013 & Dental implants & Nasal endoscopy & 16 & - & - & $3-96$ \\
\hline $\begin{array}{l}\text { The 'dobule- } \\
\text { barrel' } \\
\text { approach to } \\
\text { the (...) [17] }\end{array}$ & $\begin{array}{l}\text { Albu } \\
\text { Romania }\end{array}$ & 2013 & Dental implants & $\begin{array}{l}\text { The double barrel approach or } \\
\text { canine fossa trocar approach }\end{array}$ & 50 & $18 \%(\mathrm{n}=9)$ & $\begin{array}{l}\text { Maxillary } \\
\text { sinusitis }\end{array}$ & 12 \\
\hline \multirow{4}{*}{$\begin{array}{l}\text { Displaced dental } \\
\text { materials in } \\
\text { the maxillary } \\
\text { sinus }(\ldots)[11]\end{array}$} & \multirow{4}{*}{$\begin{array}{l}\text { Brescia } \\
\text { et al. } \\
\text { Italy }\end{array}$} & \multirow[t]{4}{*}{2019} & \multirow{4}{*}{$\begin{array}{l}\text { Dental implants (5), } \\
\text { fractured roots (2), } \\
\text { dental fillings (2), } \\
\text { bone graft, dental } \\
\text { implant and dental } \\
\text { bur }\end{array}$} & $\begin{array}{l}\text { Replaceable bone lid or pedicled } \\
\text { bone lid }\end{array}$ & 2 & - & - & \multirow[t]{4}{*}{3} \\
\hline & & & & Nasal endoscopy & 5 & - & - & \\
\hline & & & & $\begin{array}{l}\text { Nasal endoscopy }+ \text { replaceable } \\
\text { bone lid }\end{array}$ & 2 & - & - & \\
\hline & & & & Nasal combined endoscopy & 2 & - & - & \\
\hline
\end{tabular}


Afterwards, search results were put in the chronological order to eliminate duplicates.

Titles and abstracts were screened by two authors. Full texts were obtained if they were needed to decide whether to qualify the piece. Afterwards, authors obtained full texts of all included studies to analyze them in detail.

Comparative table based on included studies was constructed. The extracted data was comprised of: the type and the number of treated foreign body displacement, the methods of treatment, the late complications and the period of follow-up (Table 1).

Included studies underwent risk of bias assessment. Two authors independently analysed the contents. The quality of studies was evaluated following the criteria proposed by Cericato et al. [13] by both authors independently. The appraisal estimated as: high quality (10-12 points), moderate quality (6-9 points) and poor quality (5 and less points). Any inconsistency between the authors was resolved by discussion.

Summing up, we compared contents of selected studies using forms of narrative and tabular comparison to obtain review of treatment methods of foreign body displaced into the maxillary sinus as a complication of maxillofacial interventions.

\section{Results}

Our search revealed 398 articles on Pubmed database and 133 articles on Google Scholar database. First we screened Pubmed findings, resulting in rejection of 265 papers, which were not related to the study's concern. Another 126 articles were rejected due to not meeting inclusion criteria. 7 papers were qualified to analysis. Afterwards we

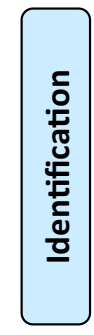

$$
\begin{gathered}
\text { Records identified through Pubmed } \\
\text { database searching } \\
(\mathrm{n}=398)
\end{gathered}
$$
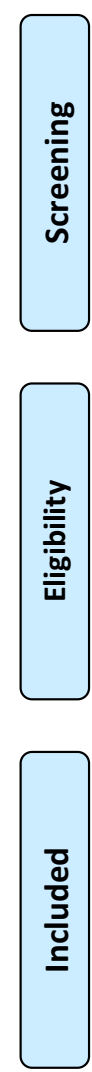

Records identified through Google Scholar database searching $(\mathrm{n}=133)$

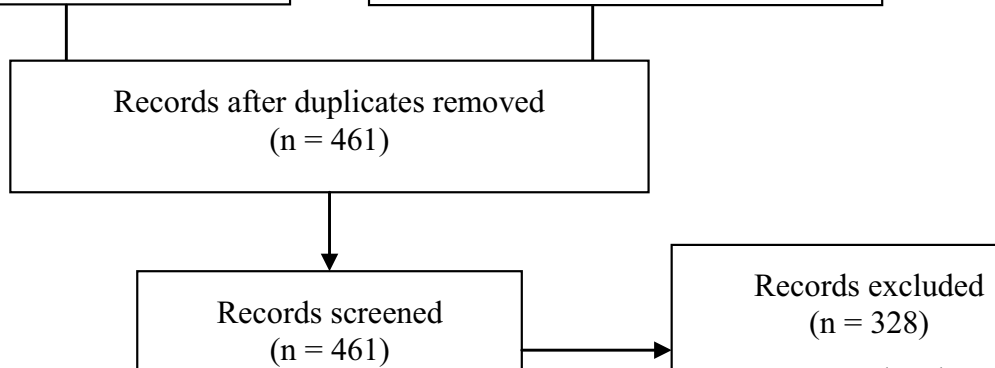

Papers not related to the review's topic

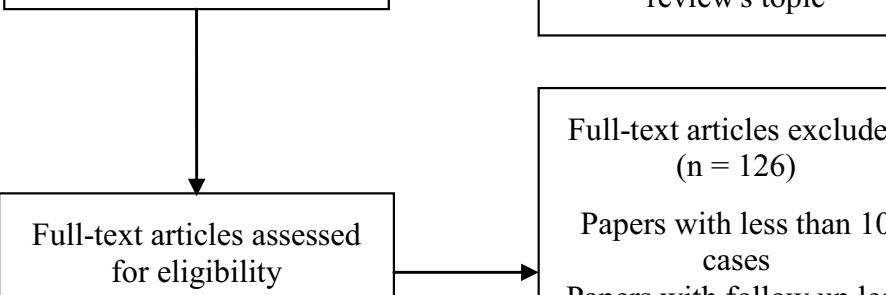

Papers with follow up less than 3 months

Reviews

Chapters of books

Fig.1 The flow diagram-evidence search and selection

Studies included in qualitative synthesis $(\mathrm{n}=7)$ 
Table 2 Quality assesment of qualified studies

\begin{tabular}{|c|c|c|c|c|c|c|c|c|c|c|c|}
\hline Title & Author & $\begin{array}{l}\text { Q.1 } \\
1 \text { point }\end{array}$ & $\begin{array}{l}\text { Q.2 } \\
1 \text { point }\end{array}$ & $\begin{array}{l}\text { Q.3 } \\
3 \text { points }\end{array}$ & $\begin{array}{l}\text { Q.4 } \\
1 \\
\text { point }\end{array}$ & $\begin{array}{l}\text { Q.5 } \\
2 \\
\text { points }\end{array}$ & $\begin{array}{l}\text { Q.6 } \\
2 \\
\text { points }\end{array}$ & $\begin{array}{l}\text { Q.7 } \\
1 \text { point }\end{array}$ & $\begin{array}{l}\text { Q.8 } \\
1 \text { point }\end{array}$ & $\begin{array}{l}\text { Amount } \\
12 \\
\text { points }\end{array}$ & Quality \\
\hline $\begin{array}{l}\text { Retrieval of root fragment in } \\
\text { maxillary } \\
\text { sinus via anterolateral wall of the } \\
\text { sinus } \\
\text { to preserve alveolar bone [2] }\end{array}$ & $\mathrm{Hu}$ et al. & + & + & - & - & ++ & - & + & - & 5 & Poor \\
\hline $\begin{array}{l}\text { The management of complications } \\
\text { following displacement of oral } \\
\text { implants } \\
\text { in the paranasal sinuses: (...) [15] }\end{array}$ & $\begin{array}{l}\text { Chiapasco } \\
\text { et al. }\end{array}$ & + & + & - & - & ++ & - & + & - & 5 & Poor \\
\hline $\begin{array}{l}\text { Complications and Management of } \\
\text { Implants Migrated into the } \\
\text { Maxillary } \\
\text { Sinus [16] }\end{array}$ & Manor et al & + & + & + & - & ++ & + & + & - & 7 & Moderate \\
\hline $\begin{array}{l}\text { Displacement of Dental Implants } \\
\text { Into } \\
\text { the Maxillary Sinus: A } \\
\text { Retrospective } \\
\text { Study of Twenty-One Patients [1] }\end{array}$ & $\begin{array}{l}\text { Sgaramella } \\
\text { et al. }\end{array}$ & + & - & + & - & ++ & - & + & - & 5 & Poor \\
\hline $\begin{array}{l}\text { Transnasal endoscopic removal of } \\
\text { dental } \\
\text { implants from the maxillary sinus } \\
{[14]}\end{array}$ & $\begin{array}{c}\text { Matti E. } \\
\text { et al }\end{array}$ & + & + & ++ & - & + & - & + & - & 6 & Moderate \\
\hline $\begin{array}{l}\text { The 'double-barrel' approach to the } \\
\text { removal of dental implants from } \\
\text { the } \\
\text { maxillary sinus [17] }\end{array}$ & Albu et al. & - & + & +++ & + & ++ & & + & - & 10 & High \\
\hline $\begin{array}{l}\text { Displaced Dental Materials in the } \\
\text { Maxillary Sinus: An Original } \\
\text { Series }\end{array}$ & $\begin{array}{l}\text { Brescia et } \\
\text { al. }\end{array}$ & + & + & + & - & + & - & + & - & 6 & Moderate \\
\hline
\end{tabular}

Q.1-Abstract contains the aim of the study, methods, results and conclusion

Q.2-The study provides ethic approval

Q.3-Presence of type of the study, criteria of inclusion and rejection, randomisation

Q.4-Presence of control group

Q.5-Size of the group (above 10 cases -1 point, above 20 cases -2 points)

Q.6-Statistical method stated, p-value stated

Q.7-The purpose and conclusions are clearly reported

Q.8-Limitations are reported

screened Google Scholar findings, resulting in rejection of: 33 papers which were not related to our topic, 35 papers which were doubled with Pubmed findings, and 65 due to not meeting inclusion criteria. 2 papers, which were doubled with Pubmed findings, were qualified to the analysis. Summary available in the Flow Diagram (Fig. 1).
Qualified studies detailed characteristics are presented in Table 1. Assessment of risk of bias within the studies is presented in Table 2.

Among analyzed studies no late complications occurred after FESS [11, 14-16], 0-5\% cases in replaceable bone lid or pedicled bone lid techniques $[1,2,11,15]$, and $15-18 \%$ in Caldwell Luc approach [16, 17]-Table 3. 
Table 3 Rate of late complications of particular method of treatment

\begin{tabular}{|c|c|c|c|c|c|c|c|c|c|}
\hline Author & FESS & $\begin{array}{l}\text { Replaceable bone lid or } \\
\text { pedicled bone lid }\end{array}$ & $\begin{array}{l}\text { Conservative } \\
\text { antrostomy (Caldwell- } \\
\text { Luc) }\end{array}$ & & & & & & \\
\hline & $\begin{array}{l}\text { Late } \\
\quad \text { complications }\end{array}$ & $\mathrm{N}$ & $\%$ & $\begin{array}{l}\text { Late } \\
\text { complications }\end{array}$ & $\mathrm{n}$ & $\%$ & $\begin{array}{l}\text { Late } \\
\text { complications }\end{array}$ & $\mathrm{n}$ & $\%$ \\
\hline $\begin{array}{l}\text { Matti et al. } \\
{[14]}\end{array}$ & 0 & 16 & $0 \%$ & - & - & - & - & - & - \\
\hline $\begin{array}{l}\text { Chiapasco } \\
\text { et al. [15] }\end{array}$ & 0 & 6 & $0 \%$ & 0 & 17 & $0 \%$ & - & - & - \\
\hline $\begin{array}{l}\text { Brescia et al. } \\
\text { [11] }\end{array}$ & 0 & 7 & $0 \%$ & 0 & 2 & $0 \%$ & - & - & - \\
\hline $\begin{array}{l}\text { Manor et al. } \\
{[16]}\end{array}$ & 0 & 1 & $0 \%$ & - & - & - & $8^{*}$ & $52 *$ & $15 \% *$ \\
\hline Hu et al. [2] & - & - & - & 1 & 21 & $5 \%$ & - & - & - \\
\hline $\begin{array}{l}\text { Sgaramella } \\
\text { et al. [1] }\end{array}$ & - & - & - & 0 & 21 & $0 \%$ & - & - & - \\
\hline $\begin{array}{l}\text { Albu et al. } \\
\text { [17] }\end{array}$ & - & - & - & - & - & - & $9 * *$ & $50 * *$ & $18 \%$ ** \\
\hline
\end{tabular}

*Lateral maxillary sinus wall antrostomy [16]

**Antrostomy through canine fossa and 'double-barrel approach'-operation through two trocars inserted via lateral wall [17]

\section{Discussion}

Displaced foreign bodies should be always removed from maxillary sinus, to prevent sinonasal complications $[1,11,14-16]$ or accidental dangerous spontaneous displacement [18].

FESS facilitates performing no intervention within the maxillary sinus wall and maintaining natural ostium drainage-resulting in low surgical trauma and low rate of complications. Nasal endoscopic techniques provide the same efficiency of foreign body removal as intraoral approaches [1] and possible inferior meatal antrostomy resolves problems with large foreign bodies and those located unfavourably to be retrieved via natural ostium $[14,19]$. Another advantage is brought by the possibility of simultaneous treatment of associated sinonasal pathologies [15]. Possible presence of oroantral fistula forces to supplement FESS with an intraoral approach $[11,15]$.

Replaceable or pedicled bone lid techniques do invade maxillary sinus wall, which is associated with postoperative facial swelling and paresthesia [2]. However these approaches restore the integrity of the maxillary bone and, partly, Shneiderian membrane [20,21], providing quite low rate of late complications $[1,2,11,15]$. They bring particular application in cases related to maxillary bone involvement [11, 15].

Conservative Caldwell-Luc operation should be performed for foreign body removal only if other techniques are not available, it brings $15-18 \%$ risk of postoperative sinusitis. Frequently appear symptoms such as: facial numbness, cheek pain, cheek swelling, teeth numbness, gingival problems associated with damage of the bone and infraorbital nerve [16, 17].

Iatrogenic foreign body migration into maxillary sinus remains relatively rare complication, though exact morbidity seems to be underestimated and still rising $[1,15]$. Lack of randomized trials and little investigated cases impede evaluation of methods of treatment in the previous literature. Therefore, the quality of included articles appeared rather weak-we assessed 1 paper as high quality, 3 papers as moderate quality and 3 papers as poor quality (Table 2). Those are the main limitations of our study.

\section{Conclusion}

To conclude, FESS probably should become a gold standard for removing foreign bodies from maxillary sinus. However, there still exist the necessity for further investigation, especially comparing FESS and replaceable or pedicled bone lid techniques using prospective, randomized studies to estimate detailed outcomes.

Acknowledgements We would like to acknowledge Adam Jankowiak for providing language help and manuscript edition.

Funding This study received no funding.

Compliance with Ethical Standards 
Conflict of interest The Authors declare that they have no conflict of interest.

Ethical Approval Ethical approval was not necessary for the preparation of this article.

Open Access This article is licensed under a Creative Commons Attribution 4.0 International License, which permits use, sharing, adaptation, distribution and reproduction in any medium or format, as long as you give appropriate credit to the original author(s) and the source, provide a link to the Creative Commons licence, and indicate if changes were made. The images or other third party material in this article are included in the article's Creative Commons licence, unless indicated otherwise in a credit line to the material. If material is not included in the article's Creative Commons licence and your intended use is not permitted by statutory regulation or exceeds the permitted use, you will need to obtain permission directly from the copyright holder. To view a copy of this licence, visit http://creativecommons.org/licenses/by/4.0/.

\section{References}

1. Sgaramella N, Tartaro G, D'Amato S, Santagata M, Colella G (2016) Displacement of dental implants into the maxillary sinus: a retrospective study of twenty-one patients: implant displacement into maxillary sinus. Clin Implant Dent Relat Res 18(1):62-72. https://doi.org/10.1111/cid.12244

2. Hu YK, Yang C, Zhou XuG, Wang Y, Abdelrehem A (2015) Retrieval of root fragment in maxillary sinus via anterolateral wall of the sinus to preserve alveolar bone. J Craniofac Surg 26(2):e81-e84. https://doi.org/10.1097/SCS.0000000000001286

3. Lazaridis N, Tilaveridis I, Venetis G, Lazaridou M (2008) Maxillary sinus osteoplasty with vascularized pedicled bone flap. Oral Surg Oral Med Oral Pathol Oral Radiol Endodontol 106(6):828-832. https://doi.org/10.1016/j.tripleo.2008.05.030

4. Tanasiewicz M, Bubilek-Bogacz A, Twardawa H, SkuchaNowak M, Szklarski T (2017) Foreign body of endodontic origin in the maxillary sinus. J Dent Sci 12(3):296-300. https://doi.org/10.1016/j.jds.2013.02.033

5. Manea C, Sarafoleanu C (2015) Iatrogenic foreign bodies in the maxillary synus: between malpraxis and medico-legal consequences. Roman J Leg Med 23(1):14-18. https://doi.org/ 10.4323/rjlm.2015.14

6. Burnham R, Bridle C (2009) Aspergillosis of the maxillary sinus secondary to a foreign body (amalgam) in the maxillary antrum. Br J Oral Maxillofac Surg 47(4):313-315. https://doi.org/ 10.1016/j.bjoms.2009.01.015

7. Krishnan S, Sharma R (2013) Iatrogenically induced foreign body of the maxillary sinus and its surgical management: a unique situation. J Craniofac Surg 24(3):e283-e284. https://doi.org/10. 1097/SCS.0b013e31828f2a5a

8. Smith JL, Emko P (2007) Management of a maxillary sinus foreign body (dental bur). Ear Nose Throat J 86(11):677-678

9. Deniz Y, Zengin A, Karli R (2016) An unusual foreign body in the maxillary sinus: dental impression material. Niger J Clin Pract 19(2):298. https://doi.org/10.4103/1119-3077.164367
10. Hasegawa $\mathbf{J}$ et al (2003) Foreign body in the maxillary sinuspossible plastic tube: a case report. Auris Nasus Larynx 30(3):299-301. https://doi.org/10.1016/S0385-8146(03)00057-9

11. Brescia G, Fusetti S, Apolloni F, Marioni G, Saia G (2019) Displaced dental materials in the maxillary sinus: an original series. analysis and definition of a surgical decision-making process. Ann Otol Rhinol Laryngol 128(3):177-183. https:// doi.org/10.1177/0003489418812898

12. Moher MD, Liberati A, Tetzlaff J, Altman DG (2009) The PRISMA group preferred reporting items for systematic reviews and meta-analyses: the prisma statement. PLoS Med 6(7):e1000097. https://doi.org/10.1371/journal.pmed.1000097

13. Cericato GO, Bittencourt MaV, Paranhos LR (2015) Validity of the assessment method of skeletal maturation by cervical vertebrae: a systematic review and meta-analysis. Dento Maxillo Fac Radiol 44(4):20140270. https://doi.org/10.1259/dmfr.20140270

14. Matti E, Emanuelli E, Pusateri A, Muniz CCS, Pagella F (2013) Transnasal endoscopic removal of dental implants from the maxillary sinus. Int J Oral Maxillofac Implant 28(3):905-910. https://doi.org/10.11607/jomi.2894

15. Chiapasco M, Felisati G, Maccari A, Borloni R, Gatti F, Di Leo F (2009) The management of complications following displacement of oral implants in the paranasal sinuses: a multicenter clinical report and proposed treatment protocols. Int $\mathrm{J}$ Oral Maxillofac Surg 38(12):1273-1278. https://doi.org/10.1016/ j.ijom.2009.09.001

16. Manor Y, Anavi Y, Gershonovitch R, Lorean A, Mijiritsky E (2018) complications and management of implants migrated into the maxillary sinus. Int J Periodontics Restor Dent 38(6):e112e118. https://doi.org/10.11607/prd.3328

17. Albu S (2013) The "double-barrel" approach to the removal of dental implants from the maxillary sinus. Int J Oral Maxillofac Surg 42(12):1529-1532. https://doi.org/10.1016/j.ijom.2013. 04.013

18. Damlar İ (2015) Disappearance of a dental implant after migration into the maxillary sinus: an unusual case. J Korean Assoc Oral Maxillofac Surg 41(5):278-280. https://doi.org/10.5125/ jkaoms.2015.41.5.278

19. Brescia G, Saia G, Apolloni F, Marioni G (2017) A novel nasal endoscopic approach for removing displaced dental implants from the maxillary sinus. Am J Otolaryngol 38(1):92-95. https://doi.org/10.1016/j.amjoto.2016.09.005

20. Biglioli F, Goisis M (2002) Access to the maxillary sinus using a bone flap on a mucosal pedicle: preliminary report. J CranioMaxillofac Surg 30(4):255-259. https://doi.org/10.1054/ jems.2002.0279

21. Sohn D-S, Jung H-S, Kim K-H, Song K-J, An H-W, Min K-H (2011) Removal of displaced foreign body from the maxillary sinus using replaceable bony windows and saline irrigation followed by suctioning of the foreign body. Implant Dent 20(2):112-117. https://doi.org/10.1097/ID.0b013e31820faf53

Publisher's Note Springer Nature remains neutral with regard to jurisdictional claims in published maps and institutional affiliations. 